\title{
Completing the helix trilogy
}

\section{Maurice Wilkins, who shared a Nobel with Crick and Watson, tells his story.}

\section{The Third Man of the Double Helix: The Autobiography of Maurice Wilkins \\ by Maurice Wilkins \\ Oxford University Press: 2003. 274 pp. \\ $£ 16.99, \$ 27.50$}

\section{Raymond Gosling}

The first story of the discovery of the structure of DNA was The Double Helix, Jim Watson's racy account in 1968 . Twenty years later, Francis Crick published What Mad Pursuit, a more scholarly heavy-going personal view of scientific discovery. The Nobel laureates' trilogy is now completed by Maurice Wilkins' autobiography, The Third Man of the Double Helix. In addition, we have Brenda Maddox's very readable biography of Rosalind Franklin (see Nature 418, 725-726; 2002). What shines through in all of these books is their common agreement that it is the importance of DNA that makes the story of the people concerned worth telling. As Crick said: "It is the molecule that has the glamour, not the scientists."

Wilkins' autobiography gives us an intimate picture of a thoughtful, introspective man who has devoted his life to the pursuit of science and its impact on society. The buoyant sense of fun in the labs at King's College London, under the strong direction of John Randall, does not emerge as clearly as it might. For the lay reader I doubt if things will leap off the page as they do in Watson's The Double Helix.

In the first three chapters, Wilkins sets out his ancestry. He establishes the provenance of his social conscience, which has so influenced his work on the social impact of science over the past two decades. But for me the book only really comes alive when we reach chapter four, "Randall's circus". However, this may be because I joined the 'circus' in 1949 and can subconsciously fill in the backdrop to the words from my first-hand knowledge. Although I didn't know until I read the book that Wilkins had tried, unsuccessfully, to persuade Randall to give Crick a job at King's College - ah, if only!

The next chapter takes the reader into the detail of DNA. This is set well into a general context, showing the breadth of Wilkins' interests and contacts with other scientists. However, his account of his first meeting with Franklin seems to be coloured heavily with hindsight. This chapter gets to the heart of their relationship, describing the growing polarization between them in their different approaches to seeking the structure of DNA. It is worth getting this book just for this chapter and the next, which portray the way that successful scientific research is often actually done - a crab-like procession of mistakes and
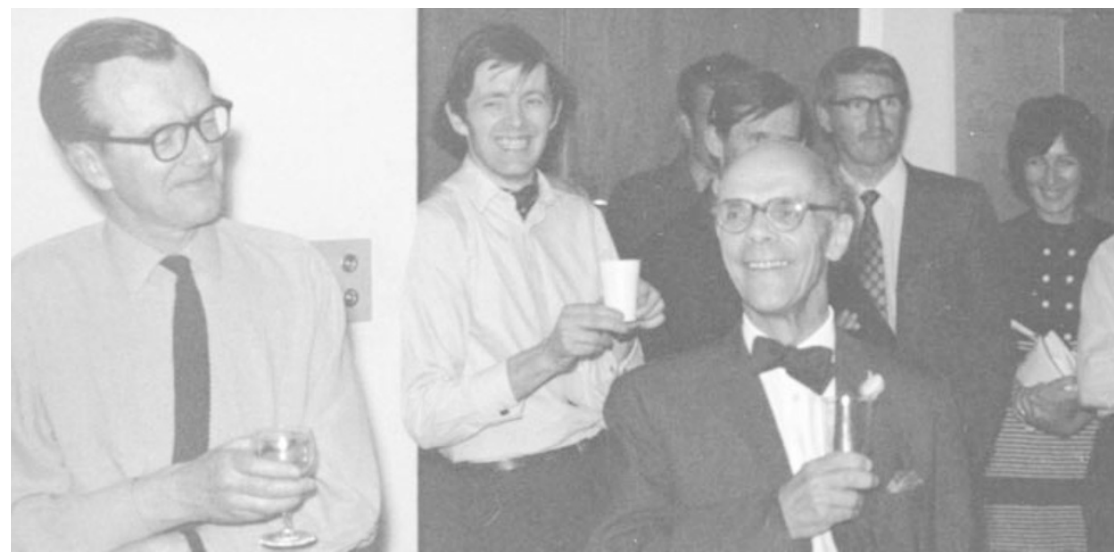

Maurice Wilkins (left) studied nucleic acids at King's College London under John Randall (right).

muddle, leading ultimately to the truth. Not at all the logical process set out in the published papers, which were written after the event.

It is fascinating to learn how close the labs in Cambridge and London came to arranging formal collaboration on DNA research, but that Wilkins turned it down, apparently with Randall's support. This led to a moratorium agreed by Randall and Lawrence Bragg, director of the Cavendish Laboratory in Cambridge, that Watson and Crick should stop working on DNA modelling.

In the chapter entitled "The Double Helix", Wilkins lays claim to having realized that Erwin Chargaff's base ratios were important to the structure of DNA. But he admits that he had not realized that specific pairing linking the phosphate-sugar strands to one another with equivalent $\mathrm{X}$-ray scattering ties would explain the predominantly helical diffraction pattern, which would be unaltered by any combination of base sequences. This has always seemed to me to have been the quantum leap that Watson made, and shows the advantages of model-building.

Wilkins eloquently describes his feelings at seeing the double-helix structure for the first time: "It seemed that non-living atoms and chemicalbonds had come together to form life itself. I was rather stunned by it all." This sums up beautifully how Franklin and I felt. It was so elegant an explanation of all of the complex properties required of DNA, and contained so many elements familiar from our own work using X-ray diffraction. At the time I did not know that Wilkins was offered co-authorship by Watson and Crick, but refused. It would certainly have been appropriate, and seems to be something that he later came to regret.

In discussing the model, Wilkins mentions many of the scientists concerned with laying the foundation of knowledge on which the structure rests. He perceptively writes: "as science becomes increasingly global and interdisciplinary, the idea of anyone standing up like someone at the top of Everest becomes increasingly inappropriate." He goes on to discuss the work that he, Herbert Wilson and their colleagues at Kings did over the next seven years to establish the correctness of the Watson-Crick model. He also writes charmingly that it was during this period that he met Patricia, who has mellowed this lonely, doubt-torn man into a happy father of four.

Chapters four to nine make most informative and interesting reading, from the discussions of X-ray diffraction to how it feels to be told by a journalist you've never heard of that you have won the Nobel Prize. However, there are three omissions from the account of the period surrounding the 1960 Lasker award, won by Wilkins, Crick and Watson: Wilkins' election to the Royal Society in 1959, his being made Companion of the British Empire in 1962, and the knighthood given to Randall for services to science in 1962 . So many personal details are proffered to the reader, yet these events are excluded; I wondered why.

I have mixed feelings about this book, written as it is by someone I worked closely with and greatly admire. I sometimes found his 'warts and all' approach to the details of his life almost embarrassing, and feel a little resentful that I will now share such intimacy with the thousands who will read the book. However, this personal account of the way in which important research was conducted may well achieve one of the author's intentions, making everyone realize that they can, and should, make the effort to play a part in influencing the way that science is shaping our world.

Raymond Gosling is emeritus professor of physics applied to medicine, United Medical and Dental Schools, University of London. Please address correspondence to Ruth Francis, King's College London, 57 Waterloo Road, London SE1 8WA, UK. 